\title{
Human-wildlife conflicts at pond fisheries in eastern Poland: perceptions and management of wildlife damage
}

\author{
Janusz Kloskowski
}

Received: 13 February 2010 /Revised: 13 August 2010/Accepted: 16 August 2010 / Published online: 2 September 2010

(C) The Author(s) 2010. This article is published with open access at Springerlink.com

\begin{abstract}
Wildlife occurring at aquacultural sites can ignite conflicts over resources managed by humans. A telephone survey concerning nuisance wildlife occurrence, perceptions of inflicted damage, and use of preventive measures at pond fisheries was conducted in 2003-2004 in eastern Poland. Significant economic losses to wildlife were reported by $80 \%$ of the respondents, with $41 \%$ claiming severe losses to more than one species. Serious damage was attributed primarily to otters Lutra lutra (56\% of farms), cormorants Phalacrocorax carbo (26\%), grey herons Ardea cinerea (23\%), and beavers Castor fiber (21\%). Two alien species, mink Neovison vison and muskrat Ondatra zibethicus, were widespread, but rarely blamed for causing substantial harm. Lethal controls were the most popular means of damage reduction and were more likely to be deployed at fish farms reporting significant losses. Cormorants, shot at half of the farms visited, were the most widely persecuted. Both otters and beavers were culled, notwithstanding their protection status and compensation payments available for beaver damage to ponds. The survey indicated poor cooperation between conservation authorities and fish farmers in managing wildlife concerns. Monitoring conflict interactions, i.e., wildlife occurrence and alleged damage at fish farms vs damage management processes, is an essential step toward conflict alleviation. Considering the wide range of species interacting with fisheries, adoption of more
\end{abstract}

Communicated by C. Gortázar

J. Kloskowski $(\bowtie)$

Department of Nature Conservation, Institute of Biology,

M. Curie-Skłodowska University,

Akademicka 19,

20-033 Lublin, Poland

e-mail: januszk1@poczta.umcs.lublin.pl flexible policies to address the conflicts than a singlespecies conservation approach is recommended.

Keywords Antipredator controls · Compensation · Fish farming · Wildlife conflict . Wildlife damage

\section{Introduction}

Pond culture is a vital economic sector of fish production in Europe (Billard 1999; FAO 2007). Pond fisheries in Central and Eastern Europe (CEE) have traditionally been dominated by cyprinid culture, mainly of common carp and the so-called Chinese carps - silver carp Hypophthalmichthys molitrix, bighead carp Aristichthys nobilis, and grass carp Ctenopharyngodon idella, frequently reared in polyculture with smaller additions of non-cyprinid fish. The total area used by cyprinid ponds in CEE exceeds 639,000 ha, with total carp production fluctuating at ca. $170,000 \mathrm{t}$ annually (Szücs et al. 2007). Since accession to the European Union (EU) in May 2004, the basic developmental goal of a large group of CEE countries is the transformation of the pond fisheries industry towards a sustainable aquaculture sector under the Common Fisheries Policy, the EU's principal instrument for aquaculture management. Such development implies an ecosystem-based pond culture aimed at maintaining biodiversity and improving the environment (FAO 2007; Szücs et al. 2007). The often spatially extensive open carp ponds, integrated with local water systems, are landscape components of great environmental importance. Unless the fish production is too intensified, carp pondcomplexes can function as wetlands supporting rich animal biodiversity (Grimmet and Jones 1989; Dobrowolski 1995; IUCN 1997). However, wildlife attracted to farm ponds by abundant food supplies and specific habitats may generate 
conflicts between animal conservation and economic interests by causing stock losses and physical destruction at aquaculture facilities (Dobrowolski 1995; Billard 1999). Increases in some wildlife populations and their spread into human-dominated landscapes are a growing concern in CEE (Adámek et al. 1997; Kranz 2000). Wildlife-related conflicts may have serious consequences both for the profitability of aquaculture enterprises, due to lost production and costs of implementing damage prevention methods (Adámek et al. 1997), and for wildlife populations, due to the cumulative adverse impact of human-mediated mortality. Some species persecuted at fisheries, such as otter Lutra lutra or beaver Castor fiber, are considered flagship species for conservation of wildlife in European wetlands (Kranz 2000; Halley and Rosell 2002).

Pond owners' observations of wildlife do not always accurately reflect the actual risk to economic yield (Freitas et al. 2007) and are likely to be biased by personal economic interest and conspicuousness of the damage (Conover 2001; Kloskowski 2005a). Nevertheless, their perceptions of damage inflicted by wild animals may be critical for the choice of means for minimizing wildliferelated losses (West and Parkhurst 2002) - to control the population size of species considered pests or to accept non-lethal methods of loss mitigation. Ratings of damage caused by wildlife may also influence involvement of public funds as pond owners may demand population culling or wildlife-related subsidies such as compensation schemes. Finally, fish farmers working close to wildlife are a potential source of information about wild populations. However, information feedback between the aquaculture industry and scientific research on wildlife-related concerns is poor in most CEE countries (cf. Young et al. 2007). Research on damage to aquacultural interests has typically been limited in scope to a single species inflicting spectacular harm (Kloskowski 1999; Adámek et al. 2003; Opačak et al. 2004). Correspondingly, institutional conservation policy takes a single-species approach (Rauschmayer et al. 2008) that may impede effective distribution of resources to mitigate the negative wildlife-fisheries interactions occurring when fish farms suffer losses inflicted by a wider range of wild species (cf. Conover and Decker 1991).

This paper reports on a telephone survey of pond fisheries staff in eastern Poland in 2003-2004 on the eve of Poland's accession to the EU in May 2004. The aim of the survey was to assess the occurrence and distribution of wildlife species that may adversely affect fisheries yield in the context of the potential impact on pond culture, to identify the most destructive species, and to obtain ratings of alleged damage. The relationship between key landscape features of the fish farms and levels of losses ascribed to individual wild species was also analyzed. The other research goal was to gather information on methods of damage control at the fisheries, including persecution of wildlife regarded as pests. A subset of the interviews was verified and supplemented by data from annual reports and hunting bags of local game clubs.

\section{Study area and methods}

A telephone survey of pond fisheries was conducted between April 2003 and April 2004. It covered the entire eastern part of Poland, bordered from the west by the river Vistula at its middle course, including farms in the western part of the Vistula watershed, up to $20^{\circ} 00^{\prime} \mathrm{E}$ (Fig. 1). Fish farms were identified by interviews in the field, aerial photographs, telephone directories, local municipalities, and district fish farming committees. Only large $(>12$ ha of water surface) fish farms were targeted, as small-scale fish culturists (for whom ponds were typically a secondary source of income) interviewed during a pilot survey frequently could not identify fish predators visiting their ponds (Kloskowski 2005a). To ensure independence of the respondents, only single fish farms were included in the analyses when the farms were densely clustered $(<10 \mathrm{~km}$ apart) or were supplied with water by the same river, on the assumption that waterways could be treated as ecological corridors by wildlife (but see also Sales-Luis et al. 2009). In such cases the first successfully contacted fish farms were included in the analyses. Difficulties obtaining telephone numbers due to poor web information and lack of a

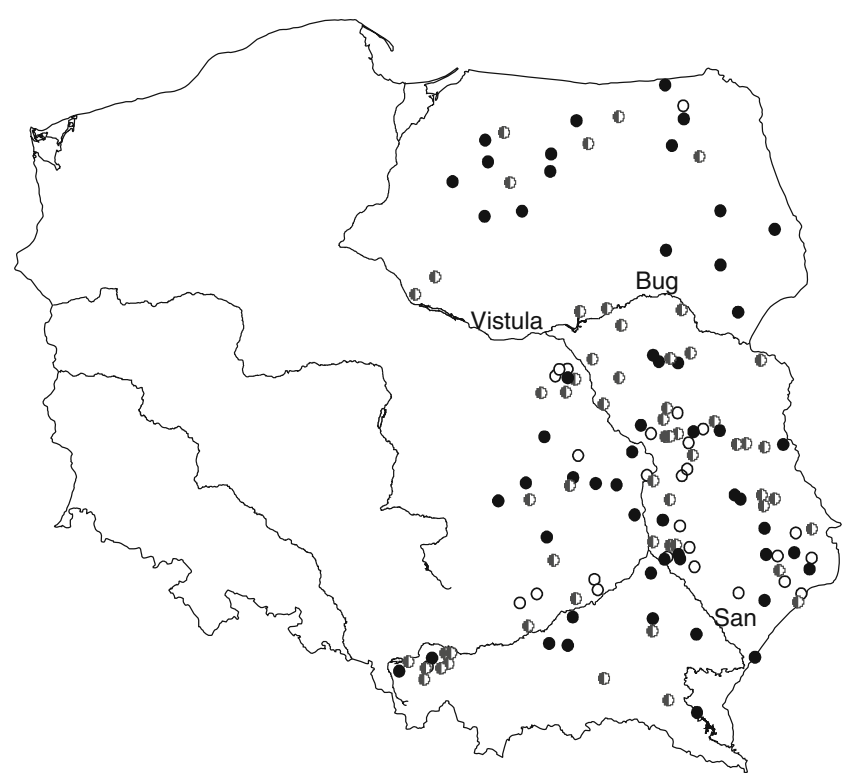

Fig. 1 Location of the 137 pond fisheries in eastern Poland included in the telephone survey; circle indicates losses to wildlife rated as tolerable; half-filled circle indicates serious losses ascribed to one species; filled circle indicates more than one species blamed for serious losses 
country-wide register of inland fisheries were the main reasons for omitting farms from the survey. The surveyed area comprised in total ca. 21,000 ha of farm ponds. The spatial distribution of pond farms in the surveyed region was uneven: in south-eastern Poland, which has few natural lakes, a dense web of pond complexes has been established, while in the northernmost part of the country, where fisheries rely on abundant natural lakes, pond farms are sparsely distributed (Dobrowolski 1995). Consequently, fewer farms were surveyed in north-eastern Poland (Fig. 1). Notwithstanding, on the basis of aerial images it was estimated that the farms included in the analyses $(n=137)$ encompassed $>60 \%$ of larger aquaculture facilities operating at the time in all $100 \times$ $100 \mathrm{~km}$ UTM squares of the surveyed area.

Telephone surveys are presumed to be superior to visiting the interviewees or to postal surveys when questions pertain to "sensitive" issues (Sellitz et al. 1965; Brace 2004), i.e., when information is requested that might be viewed as incriminating (see below). Biases associated with respondents' attempts to impress the interviewer (e.g., about the levels of wildlife damage) are likely to be lower than in face-to-face meetings (Brace 2004). Also, postal surveys on wildlife typically have low response rates (Carss 1994; Callaghan et al. 1998) and risk the nonresponse bias occurring when persons more interested in the issues covered by the survey are more likely to respond (McKinstry and Anderson 1999; Conover 2001). The interview design was pilot-tested in spring of 2003 in a survey of 40 farms focusing on the impact of otters at farmed fisheries in south-eastern Poland. Its format was extended to include more detailed information on other wildlife. Consequently, information included in the present data set on otters from 80 farms in south-eastern Poland has been used in a previous paper (Kloskowski 2005a). In the pilot survey, otters, grey herons Ardea cinerea, cormorants Phalacrocorax carbo, and beavers were the species most frequently blamed for reducing yield. Although rarely implicated in losses at fisheries, two alien invasive amphibious mammals, mink Neovison vison and muskrat Ondatra zibethicus, were often mentioned as well. Therefore, the following survey focused on these six species. According to regulations of the Polish Ministry of Environment from September 2001 (Act No. 130/14551456), cormorants, otters, and beavers were either strictly or partially protected, but at sites regarded by law as fishery precincts (areas recognized by local municipalities as reserved for aquaculture), cormorants were not protected, while beavers and otters could be culled with local-level (voivodship) or state-level (ministry) permission, respectively. Beaver damage was covered by compensation programs administered by voivodship conservation authorities. Grey heron, mink, and muskrat were game species under hunting legislation (Act No. 43/488, May 2001).
All telephone calls were made by the same person to ensure consistency in interpretation of responses. Upon initial contact, the interviewer briefly explained the purpose of the study, stressing its scientific character, and asked to speak to a high-position staff member employed with the farm for a long time and familiar with local wildlife. The interviewees were pond owners, fisheries managers, or fish farm ichthyologists (hereafter "fish farmers"). Only facilities represented by interviewees employed with the farm for at least 10 years were included in the analyses. Once the fishery staff had been successfully contacted, it was not difficult to find such respondents. Most of the sampled facilities were established $>40$ years ago and run for years as state-owned enterprises, and the fish farmers were typically local employees of many years' standing. The respondents were allowed to choose the time of day for the interview. None of the fisheries refused to cooperate, but four farms were disregarded because their owners were unwilling to answer more than one question. Interviews with one unanswered question (typically on methods of damage prevention; see below) were included in the analyses. The interviewees were asked in a standard way whether any economic losses at their farms were currently attributable to wildlife and which species inflicted the greatest harm. They were then asked to classify the impact of species recorded at their farms into two categories: (1) tolerable level of damage caused by a given species or (2) serious loss of yield caused by the species. In the latter case interviewees were asked about the type of alleged damage. If the interviewees did not mention any of the focus species, they were asked about their occurrence and impact. Further questions addressed damage control methods: whether any other than routine shooting by hunters were deployed and whether they were effective. Again, when the interviewee did not mention protective measures against any of the species cited earlier as inflicting damage, additional questions were asked pertaining to these species. The interviewer did not inquire about the legality of the damage prevention tools employed, as in the pilot survey some respondents queried about culling permits reacted with apparent mistrust and unwillingness to describe damage controls in general. Complaints about beaver led to a question about compensation claims. Interviewees representing ponds visited by otters or minks were asked whether the visiting rates by these species at their farms had changed over the last 10 years. The final section focused on information on the farm and the interviewee: farm size (the total surface area of farm ponds), property ownership, pond location, water supply to the ponds, species and age-classes farmed, and whether the interviewee had a hunting license.

A possible bias of wildlife surveys whose respondents are not educated wildlife experts is improper species 
identification. However, a field verification of otter observations at aquaculture facilities indicated that professional fish farmers could reliably recognize large vertebrates visiting their ponds (Kloskowski 2005a). In the present study, to evaluate the accuracy of interviewees' presence/ absence ratings of mink and muskrat (two smaller and less common species), a subset of the data was compared with annual game club reports from 1 April 2003 to 31 March 2004 hunting season, from the game districts in which the surveyed fish farms were located. These were Polish Hunting Association game clubs from the Lublin voivodship (ca. 25,000 $\mathrm{km}^{2}$ ), covering most of the central part of the surveyed area bordered by the rivers Vistula, Bug, and San (Fig. 1). As there could be information flow between fish farmers and hunters, to increase independence of samples, only interviewees declaring themselves not to be hunters were included in the analyses $(n=30)$. Hunting bags of the game clubs were used to supplement information on wildlife control at pond fisheries. Also, to verify the interviews, registers were obtained of compensation claims issued or supervised by government agencies of the Lublin voivodship in 2003-2004 for damage inflicted by wildlife.

\section{Data analyses}

To determine farm characteristics discriminating between farms with different levels of reported losses, a general discriminant analysis (GDA) was used. GDA is a method applying general linear model procedures to discriminant function analysis (STATISTICA 6, Statsoft Inc. 2001). All predictor variables (both continuous and categorical) were entered, then variables which contributed least to the between-group differences were systematically eliminated. Wilk's $\lambda$ was used to assess the effectiveness of the analysis in separating farm groups. This method was performed separately for species most frequently blamed for damage at fisheries. Explanatory variables included total pond surface area; northing and easting of the farm location based on $10 \mathrm{kmUTM}$ grid squares recoded to decimal values; type of water supply (a river vs precipitation or springs; rivers could be used by wildlife as waterways facilitating access to the ponds); urbanized vs "natural" landscape - a fish farm was assumed to be situated in an urbanized habitat when at least one side of the polygon created by the collective shoreline of the farm ponds was directly adjacent $(<50 \mathrm{~m})$ to a densely built-up residential area. The two latter variables were treated as nominal factors. As many of the fish farmers indicated the Vistula River and large lake complexes as wildlife concentration sites, especially of cormorants and herons, GDA included the distance from the closest large lake ( $>100$ ha), or from the river in the case of fish farms located in the Vistula river valley, as predictor variable. When necessary, landscape metrics were calculated from digitized charts or assessed from aerial photos. GDA was also performed for mink and muskrat, with their presence/absence as the categorical grouping variable. In mink and muskrat models, otter and mink presence/absence were added, respectively, as categorical predictors, on the assumption of strong trophic interactions between these species (Bonesi and Macdonald 2004; McDonald et al. 2007; Brzeziński et al. 2009). Continuous variables were log-transformed.

The strength of association between two dichotomous variables, e.g., between the level of damage ascribed by the fish farmers to individual species (serious vs tolerable losses) and occurrence of kills, was quantified with the phi-coefficient. The significance of $\varphi$ was determined by reference to the value of $\chi^{2}$ (Daniel 1990). The kappa coefficient was used to measure the extent of agreement between hunters' and fish farmers' observations of mink and muskrat (both expressed in terms of presence/ absence). $K$ values in the range $0.60-0.80$ roughly represent substantial agreement between observations, and those $>0.80$ indicate almost perfect similarity (Landis and Koch 1977).

\section{Results}

Wildlife occurrence and damage perceptions at pond fisheries

Serious damage by wildlife was reported at 110 farms $(80 \%)$, and more than one wild species was implicated in substantial damage at 56 sites $(41 \%)$. Forty-one interviewees $(30 \%)$ reported serious losses inflicted by both mammals and piscivorous birds. Otters and grey herons were the most prevalent predators on cultured fish, with both species observed at $>94 \%$ of surveyed farms. Otter numbers were felt by $61 \%$ of interviewees to have increased at their farms over the last 10 years. Otters and cormorants had the highest damage ratings; both otter and cormorant were perceived to inflict serious damage at over a half of the sites where they were observed (Table 1), whereas heron were blamed for severe financial losses at only $24 \%$ of farms visited. Both otter and the piscivorous birds were blamed for consuming economically significant quantities of cultured fish. However, 26 of 77 and 5 of 35 farmers experiencing significant stock depredation by otters and cormorants, respectively, cited indirect fish losses resulting from stress, injuries, and in the case of otters, from disturbance in winter as even more detrimental than direct consumption. Otter was the only species believed to be responsible for losses of large "marketable" fish, i.e., stocks of the greatest economic value. At 27 farms (21\% of visited sites), otter was either reported to prey selectively on 
Table 1 Numbers (percentages) of fish farms with different ratings of economic losses attributed to wildlife

\begin{tabular}{lclc}
\hline \multirow{2}{*}{ Species } & \multicolumn{3}{l}{ Losses } \\
\cline { 2 - 4 } & Serious (intolerable) & Tolerable & None \\
\hline Cormorant & $35(25.6 \%)$ & $31(22.6 \%)$ & $71(51.8 \%)$ \\
Grey heron & $32(23.4 \%)$ & $99(72.2 \%)$ & $6(4.4 \%)$ \\
Beaver & $29(21.2 \%)$ & $63(46.0 \%)$ & $45(32.8 \%)$ \\
Otter & $77(56.2 \%)$ & $52(38.0 \%)$ & $8(5.8 \%)$ \\
Mink & $7(5.3 \%)$ & $62(46.6 \%)$ & $64(48.1 \%)$ \\
\hline
\end{tabular}

Listed are species identified as causing serious damage by $>5 \%$ of the interviewees

large fish or blamed for particularly severe damage to older fish cohorts. Beaver was felt to inflict intolerable damage at $21 \%$ of the surveyed farms, with damage complaints focusing on destruction of pond levees. Two respondents blamed beaver activity for facilitating fish predation by herons by reducing pond water levels. Sixteen farms (12\%) were visited by all species with the strongest impact, i.e., otters, cormorants, beavers, and herons.

GDA showed that perceived adverse effects of cormorant and beaver tended to increase in a northerly direction (Table 2). The vulnerability of fish stocks to cormorants was also influenced by the size of the fish farm and its proximity to large natural waters (Table 2). None of the characteristics analyzed significantly distinguished between fish farms with different ratings of stock losses to otters or herons.

Mink occurred at $52 \%$ of farms and was widespread over eastern Poland (Table 1). However, the GDA showed that it was more common in the northern part (Wilk's $\lambda=0.770$; $\left.F_{1,122}=36.48, p<0.001\right)$. It was also more likely to to be reported at farms where otters were observed (Wilk's $\lambda=$ $0.968 ; F_{1,122}=36.48, p=0.048$ ). Mink was the only species occasionally difficult to recognize by fish farmers; four interviewees stated that they were unable to identify mink to species. However, fish farmers' perceptions of mink occurrence and local hunting reports showed substantial agreement $(K=0.795 \pm 0.120 \mathrm{SE} ; 95 \%$ confidence intervals: $0.575-1)$. Moreover, many mink observations were based on "hard" evidence: findings of dead individuals, snared animals, or food caches consisting of fish. Species confusion between otter and mink seems unlikely to seriously bias the data: 68 of 69 mink records came from farms visited by otters and the fish farmers usually differentiated the type of damage inflicted by the two species, typically claiming depredation by mink to be confined to the smaller stock. A majority of interviewees assessed the time period of mink presence at their farms as $<15$ years; only one pond owner (a hunter) from north-eastern Poland claimed that minks had visited his farm since the mid-1970s. However, ten respondents representing farms with mink (all of them visited by otters) believed that following an expansion phase, mink numbers had significantly declined at their ponds in the last 2-3 years.

Muskrats were recorded at 81 farms (59\%) and although commonly blamed for digging in dams, were regarded as a problem species of economic significance at only one farm. As in the case of mink, the kappa statistic indicated a strong similarity between muskrat presence/absence ratings by fish farmers and hunting bag data $(K=0.630 \pm 0.166 \mathrm{SE} ; 95 \%$ confidence intervals: $0.303-0.956)$. Muskrat occurrence at aquaculture facilities was negatively associated with mink presence (Wilk's $\lambda=0.915 ; F_{1,122}=11.30, p<0.001$ ). At all farms where muskrats were believed to be absent, the species had been observed earlier. Additionally, on 11 farms with muskrat where mink were reported to be present, interviewers estimated (unrequested) that muskrats were

Table 2 Results of the general discriminant analysis for fish farms with different levels of economic losses attributed to wildlife

\begin{tabular}{|c|c|c|c|c|c|c|}
\hline & Free from concerns & Tolerable losses perceived & Serious losses perceived & Wilk's $\lambda$ & $F$ & df \\
\hline \multicolumn{7}{|l|}{ Cormorant } \\
\hline Farm size (ha) & $66.7 \pm 2.2$ & $136.7 \pm 2.3$ & $146.9 \pm 3.0$ & 0.849 & $11.719 * *$ & 2,132 \\
\hline Northing $^{\mathrm{a}}$ & $50.93 \pm 0.83$ & $51.29 \pm 1.13$ & $52.00 \pm 1.64$ & 0.867 & $10.079 * *$ & 2,132 \\
\hline $\begin{array}{l}\text { Distance from the closest } \\
\text { large lake/river }(\mathrm{km}) \\
\text { Beaver }\end{array}$ & $27.3 \pm 2.0$ & $22.7 \pm 2.4$ & $12.8 \pm 2.6$ & 0.897 & $7.537 * *$ & 2,132 \\
\hline Northing $^{\mathrm{a}}$ & $50.92 \pm 0.96$ & $51.40 \pm 1.38$ & $51.40 \pm 1.14$ & 0.964 & $3.264^{*}$ & 2,134 \\
\hline
\end{tabular}


rare or decreasing in numbers. However, muskrats were also perceived to be decreasing at 13 farms where mink were not observed.

Losses to great white egrets Egretta alba exceeded the tolerance of five farmers (4\%), while 16 interviewees (12\%) indicated (unrequested) an increase in egret visits to their ponds. The remaining wild species occasionally considered to be a nuisance (in all cases by $<3 \%$ of the interviewees) were night heron Nycticorax nycticorax, mute swan Cygnus olor (due to feeding on cereals fed to fish), merganser Mergus merganser, osprey Pandion haliaetus and whitetailed eagle Haliaetus albicilla.

\section{Damage mitigation measures}

Damage control measures were employed at 74 farms $(58 \%)$. The most popular were lethal controls, reported at 58 farms (42\%). Cormorant, declared to be shot at 33 fish farms (Table 3), was the most widely culled species at fisheries. Lethal methods were commonly deployed to limit cormorant depredation, though all but two of the 14 farms that used non-lethal scaring devices against cormorants (gas cannons, firecrackers, shooting to harass birds) rated them effective in keeping cormorants away from the ponds. Three interviewees mentioned cutting down trees used by cormorants for nesting or perching in the neighborhood of ponds. The devices used against cormorants were routinely targeted at herons as well (11\% of farms with herons), but no deterrents were used specifically against herons. The remaining nuisance species were reported to be culled at $<20 \%$ of the sampled facilities where they occurred (Table 3). Under-reporting of otter persecution was obvious, because seven respondents ( $5 \%$ farms visited by otters) did not want to talk by telephone about methods of reducing losses to this species, or vaguely said that animals were "effectively removed" from their farms. Visits to

Table 3 Summary data for fish farms where lethal methods of damage control were employed

\begin{tabular}{lllrr}
\hline Species & $\begin{array}{l}\text { Number of farms where } \\
\text { lethal control was used } \\
\text { (\% of the species } \\
\text { occurrence sites) }\end{array}$ & & & \\
& $33(50.0 \%)$ & 0.404 & 22.6 & $<0.001$ \\
\hline Cormorant & $26(19.8 \%)$ & 0.207 & 5.62 & 0.018 \\
Grey heron & $13(14.1 \%)$ & 0.531 & 25.91 & $<0.001$ \\
Beaver & $25(19.7 \%)$ & 0.203 & 5.32 & 0.021 \\
Otter & & & & \\
\hline
\end{tabular}

Correlation coefficients between perceived levels of losses and occurrence of wildlife persecution are presented. The value of $\varphi$ was tested against the relevant value of $\chi^{2}$. Listed are species culled by fisheries staff at $>10$ farms ponds and occasional information from other sources suggested that illicit killing of otters was common, even when not admitted by the interviewees, but responsibility for the killing was not clear. Four respondents (3\% of farms visited by otters) reported otter snare-trapping by poachers due to the alleged recent return of the fur market. Some interviewees indirectly indicated that they killed otters illegally because obtaining permits for culling the strictly protected species was complicated. Farmers rarely deployed non-lethal antipredator controls to curb otter predation $(5 \%$ of farms visited by otters), and only two respondents (2\%), both using electric fences around ponds holding overwintering fish, considered them effective. Only one pond owner claimed to have permission for live-trapping and translocation of otters, but with poor capture success (one individual was trapped).

In no case did wildlife authorities reimburse pond owners for non-lethal methods of damage reduction. Noninvasive prevention of beaver damage (construction of metal net fences along critical sites at levees) has been planned by only one farmer on condition of receiving a subsidy. Twenty-four farmers $(18 \%)$ received ex-post compensation paid from government funds for alleged beaver damage to levees, culverts, and irrigation structures. However, six of them culled beavers, claiming the payments were unsatisfactory because they pertained only to damage to levees and not to the value of stock fish that might be liberated after collapse of a pond levee.

Although the interview design did not include additional detailed questions on culling practices, a significant proportion of kills reported as authorized seemed to occur in a legal grey area. Although 36 fish farmers (26\%) were licensed hunters, other methods than authorized shooting were apparently common. Persecution of mammalian intruders included cruelty cases such as clubbing of otters at ice holes or deliberate use of fierce dogs. On the other hand, the interviewees routinely complained that hunters showed no interest in shooting non-game nuisance species. Hunting bags indicated that herons were shot in 27 of 62 hunting districts containing fish farms, muskrats in 38 and minks in eight, where hunting statistics were available. However, figures on animals harvested directly at fish farms remain unknown.

Fish farmers experiencing significant losses to the principal problem species were more likely to employ lethal control of these species than farmers with losses that could be accommodated (Table 3). Similarly, mink and muskrat were actively persecuted (shooting, trapping, snares) by fishery staff wherever they were alleged to inflict substantial damage. Among farms with serious losses, culling was more likely to be practiced when more than one wild species was blamed for serious financial losses $\left(\varphi=0.365, \chi^{2}=18.24, p<0.001\right)$. 


\section{Discussion}

Occurrence of nuisance wildlife and damage perceptions at pond fisheries

Serious losses to wildlife were commonly reported at pond fisheries, and more than one species created problems of economic significance at $41 \%$ of surveyed farms. Otters dominated the aquacultural damage; they were widely reported and believed to be responsible for severe stock losses at over a half the sites where they were observed. Various features of the species' ecology might contribute to the otter's notorious reputation (Kranz 2000; Adámek et al. 2003). In contrast to avian predators, otters are year-round visitors at farms. As they are little constrained by prey fish size, larger-sized fish cohorts with the greatest market value are vulnerable to otter depredation (Kloskowski 2005b). Relatively high damage ratings placed cormorant as the second most destructive species. Although the least widespread of the survey's focus species, it was the most widely killed species at the farms.

Populations of all focus species were widely dispersed across the fish farms in eastern Poland. Increases in ratings of damage from cormorants and beavers along the northward gradient are not surprising, as the lakelands in north-eastern Poland have traditionally been population strongholds for both species (Żurowski and Kasperczyk 1988; Tomiałojć and Stawarczyk 2003). Geographical differences in levels of menace attributed to cormorants were in line with greater perceived losses at farms situated close to large natural waterbodies. The latter apparently provided flyways and source habitats for cormorants, while at fish farms the birds were intensely persecuted (cf. Callaghan et al. 1998). In fact, in the central part of the surveyed area (bordered by the Bug and San rivers), which lacks large natural lakes, all cormorant nest colonies have been abandoned since 2000 due to persecution (Tomiałojć and Stawarczyk 2003). Also, cormorants were more likely to cause significant losses to the larger farms, typically including large ponds, which offered more safety to foraging birds (Callaghan et al. 1998). No specific characteristics predisposing fish farms to otter and heron depredation were detected, presumably because the two species were so widespread.

The present survey shows that monitoring fish farms may yield a substantial amount of population data on wildlife interacting with fisheries. This may be especially valuable in the case of mammals, for which monitoring schemes are less developed than those for birds and which are also frequently more difficult to monitor than most bird species (Battersby and Greenwood 2004). The perceived increase in otter visiting rates confirms the growing population trend in Poland (Brzeziński et al. 1996). Mink was widespread over the entire study area, but it was most frequently reported in north-eastern Poland, where its invasion began (Brzeziński and Marzec 2003), so further colonization is to be expected. Mink were more likely to be observed at farms visited by otters, indicating that otter impact on mink was insignificant in pond culture areas (see also Jędrzejewska et al. 2001), but mink was also believed to decrease at some farms visited by otters. Also, the present results confirm that mink may be an agent of muskrat decline (Erb et al. 2001; Brzeziński et al. 2009). The observations and accompanying complaints about great white egret, a species absent from Poland for over a century, but recently rapidly expanding (Tomiałojć and Stawarczyk 2003), may portend an emerging conflict. While perceptions of damage intensity may be highly subjective, fish farm personnel appear a reasonably reliable source (although supplementary to a better standardized monitoring effort) of presence/absence records of large and medium-sized amphibious mammals and birds at fish ponds. Bearing in mind the importance of fish ponds as local hotspots of wildlife diversity in CE Europe (IUCN 1997), wildlife observations from fish farms may be useful for atlas data and assessment of population dynamics.

\section{Damage prevention and wildlife persecution}

According to fish farmers, non-lethal methods were not viable means of damage control and their use against species other than cormorants was very rare. Culling of problem animals was common at fish farms, targeting both protected and game species. The positive relationship between occurrence of lethal control and the perceived magnitude of losses to wildlife highlights the predictive role of damage perceptions for damage prevention strategies (cf. Coluccy et al. 2001). It also indicates that lethal control has been employed in a "corrective mode" (Conover 2001), i.e., after damage has already begun. Still, the information on wildlife killing obtained from the interviews should be treated only as an indication of the actual scale of the problem because occurrence of lethal persecution of species protected by law was apparently seriously underestimated (cf. Carss 1994).

Some previously endangered problem species have rapidly recovered in Poland in recent decades (Brzeziński et al. 1996; Dzięciołowski and Goździewski 1999; Tomiałojć and Stawarczyk 2003) and fish farmers have had to deal with new challenges. Many interviewees expressed their disappointment that no visible institutional attempts had been made to intervene in offsetting losses to steadily growing protected populations of otters and beavers. Lack of information on damage mitigation measures and frustration over the unresponsiveness of government agencies with regard to dealing with nuisance 
wildlife might exacerbate controversies over how to manage the problem and fish farmers' antagonism toward conservation law (cf. Conover and Decker 1991; Sales-Luis et al. 2009). The situation was additionally complicated by restrictions by the Ministry of the Interior and Administration on granting firearms certificates (Act No. 19/240, March 2000), essentially banning the use of firearms against problem animals at fisheries by persons other than hunters. Consequently, illegal persecution appeared to be widespread at pond fisheries and its extent is probably much greater than that revealed by the survey. Also, culling practices other than licensed shooting raise additional ethical and legal concerns.

The overall picture of damage mitigation strategies shows that when thriving wildlife populations are targeted, there is no easy path to conflict reconciliation. Large-scale culling of large vertebrates, including charismatic species, raises concerns about animal welfare and risks to wildlife populations in the long term (Baker et al. 2008). Also, outright elimination of intruders does not necessarily help to reduce the attractiveness of cultured resources for the targeted species in the long term (van Vessem et al. 1985; Berger 2006). Compensation schemes paid from government funds can mitigate the economic motivation of resource owners to cull nuisance wildlife (Schwerdtner and Gruber 2007; Treves et al. 2009), but they routinely face criticism for fraud, inadequacy, and continuously mounting costs (Saberwal et al. 1994; Bulte and Rondeau 2005). Between 2003 and 2009, the number of compensation payments for beaver damage in the Lublin voivodship has increased fourfold (Lublin Regional Directorate for Environmental Protection files); hence, sustainability of the compensation mechanisms over the long term is questionable. Apart from budgetary concerns, compensation payments for damage caused by beavers in eastern Poland did not entirely remove incentives to pursue culling. A promising alternative would be a rational reallocation of available financial resources from compensations to subsidies for implementing non-lethal methods for limiting wildlife use of cultured resources, at least as complementary to lethal actions for population management. Financial aid for purchase of equipment to protect fish farms from natural predators is foreseen by Axis 2 of the European Fisheries Fund 2007-2013, the main EU instrument for fisheries programming (Council Regulation No 1198/2006). Some non-lethal methods were rated effective by the interviewees, but further independent research on their efficacy is required. However, non-lethal techniques, while least controversial, may relieve wildlife pressure on human resources only locally, in that discouraged animals may simply move to other pond complexes. There is rather a need for adopting a mix of local-scale, flexible strategies, integrating regulated population management (e.g., directed hunting; Dzięciołowski and Goździewski 1999; Treves and
Karanth 2003) but protecting wildlife from excessive and uncontrolled decimation. Moving decision-making processes to the local level, with the participation of the main interest groups (fish farmers, game clubs, and conservation authorities), can accommodate the self-determination aspirations of the stakeholders (Treves and Karanth 2003). Regulated hunting or culling based on adaptive legislation may raise fish farmers' tolerance for destructive species by assuring them that the offenders will not remain "unpunished." The present survey did not address respondents' opinions as to whether hunters adequately reduce wildlife pressure on fish farm resources, as among the principal problem species grey heron was the only game species. However, given heron's high depredation potential at fisheries (Lekuona 2002), heron damage ratings and the percentage of facilities where herons were killed by the staff were relatively low compared to cormorants (which were not harvested by hunters), presumably because owners of ponds used as hunting grounds knew of the hunting effort. The practical question is to determine at what level of wildlife losses subsidized investments into damage management practices are reasonable. The present results show that if otters or cormorants were present at ponds, they were most likely posing serious economic problems for the fish farmers. Therefore, verified regular occurrence of these species at fish farms should justify institutional intervention of government agencies. However, due to unavoidable funding constraints and to reduce opportunities for fraud only fishery precincts should be eligible for subsidies. More varied payment mechanisms could involve diverse (i.e., other than governmental) sources of funding.

A related problem is adequate assistance in managing wildlife damage at fish farms suffering costs from multiple problem species. Financial burdens on this group of farms may by particularly heavy, both due to the different types of production losses to species with differing impact on farm resources (e.g., piscivorous birds taking fish and beavers burrowing into levees) and because protective measures against different groups of nuisance species require greater expenditures. Aquaculture facilities visited by a wider range of wildlife are likely to be habitats of high conservation value and their environmental role additionally justifies institutional support from local authorities. Conflicts caused by a greater range of wildlife require context-dependent conservation policy going beyond the currently prevalent single-species approach (cf. Barrows et al. 2005). Management of such conflicts should rely on locally feasible options and on a more equitable distribution of public funds (also see Treves et al. 2009). For instance, there is no compelling reason to favor the successfully reintroduced beavers as a single species included in the damage compensation schemes at fisheries in Poland, as its population is no less stable than that of other species 
involved in economic losses at fish farms (Halley and Rosell 2002).

As shown by the survey, some of the fish farmers in eastern Poland killed nuisance beavers, without applying for compensation payments or in spite of receiving them. This indicates that administrative indicators of the scale of wildlife problems, such as registers of compensation claims or compensation payments, cannot replace independent monitoring of conflicts and conflict management processes at fisheries. Monitoring activities should cover interactions between the parties of the wildlife-fisheries conflict and not just one aspect of the conflict (also see Young et al. 2007; Henle et al. 2008). Sound wildlife censuses and monitoring of damage inflicted at fisheries should be accompanied by monitoring of damage perceptions and of prevention measures taken, documenting the extent of lethal control operations. Such an approach may help to ensure both that farm enterprises are not exposed to economically devastating impacts of wildlife and that wildlife populations are not too strongly affected by lethal controls. However, there are no simple solutions for integrated adoption of these strategies at an industry-wide level. Damage perceptions by property owners, while a useful indicator of the intensity of wildlife-fisheries conflicts, are only a proxy for the actual severity of losses (Conover 2001), while standardized quantitative methods of damage assessment are costly and labor-intensive (Freitas et al. 2007; Sales-Luis et al. 2009). Also, obtaining accurate records of wildlife kills is difficult because illegal persecution is usually concealed (but see Carss 1994).

The survey reveals poor cooperation between conservation authorities and aquaculture facility operators in alleviating wildlife-related conflicts in Poland. Insufficient assistance to fisheries with wildlife problems by government agencies restrained by inflexible law and budgetary limitations is largely responsible for this situation. The only institutional participatory response to the escalating wildlife-fisheries conflict has been compensation schemes for beaver damages. Since Poland's accession to the EU, the dominant role of lethal means for controlling losses to wildlife at commercial fisheries has even increased. The Ministry of Environment delisted otters from the strictly protected species list in September 2004 (depriving them of any protection status at fishery precincts), and grey herons from the game species list in March 2005 (Act No. 220/ 2237, Annex 2 and Act 45/433, respectively). These changes in protection status have in practice allowed unrestricted reduction of these species at larger fish farms. Of the principal species that adversely interact with pond culture, only beaver remains partially protected at fishery precincts. Also, beavers and otters benefit from Natura 2000 protection status at ponds belonging to the Natura 2000 network (Annex II of the EC Habitats Directive).
Given the popularity of open pond culture and the likelihood that some nuisance populations will continue to increase in Poland, integrated implementation of adaptive conflict resolution strategies on condition of cooperation of all major interest groups (cf. Rauschmayer et al. 2008) is a necessary and urgent endeavor to avoid the continuing scenario of widespread economic losses and massive wildlife persecution at pond fisheries.

Acknowledgments I am grateful for the collaboration of the fish farmers. Thanks to the Polish Hunting Association in Lublin for the access to hunting statistics.

Open Access This article is distributed under the terms of the Creative Commons Attribution Noncommercial License which permits any noncommercial use, distribution, and reproduction in any medium, provided the original author(s) and source are credited.

\section{References}

Adámek Z, Klinger H, Staub E (1997) Cormorants in Europe - the evaluation of EIFAC/FAO questionnaire campaign. Suppl Ric Biol Selvag 26:347-353

Adámek Z, Kortan D, Lepic P, Andreji J (2003) Impacts of otter (Lutra lutra) predation on fishponds: a study of fish remains at ponds in the Czech Republic. Aquac Int 11:389-396

Baker PJ, Boitani L, Harris S, Saunders G, White PCL (2008) Terrestrial carnivores and human food production: impact and management. Mamm Rev 38:123-166

Barrows CW, Swartz MB, Hodges WL, Allen MF, Rotenberry JT, Li BL, Scott TA, Chen XW (2005) A framework for monitoring multiplespecies conservation plans. J Wildl Manage 69:1333-1345

Battersby JE, Greenwood JD (2004) Monitoring terrestrial mammals in the UK: past, present and future, using lessons from the bird world. Mamm Rev 34:3-29

Berger KM (2006) Carnivore-livestock conflicts: effects of subsidized predator control and economic correlates on the sheep industry. Conserv Biol 20:751-761

Billard R (ed) (1999) Carp: biology and culture. Springer, Berlin

Bonesi L, Macdonald DW (2004) Impact of released Eurasian otters on a population of American mink: a test using an experimental approach. Oikos 106:9-18

Brace I (2004) Questionnaire design. How to plan, structure and write survey material for effective market research. Kogan Page, London

Brzeziński M, Marzec M (2003) The origin, dispersal and distribution of the American mink Mustela vison in Poland. Acta Theriol 48:505-514

Brzeziński M, Romanowski J, Cygan JP, Pabin B (1996) Otter Lutra lutra distribution in Poland. Acta Theriol 41:113-126

Brzeziński M, Romanowski J, Żmihorski M, Karpowicz K (2009) Muskrat (Ondatra zibethicus) decline after the expansion of American mink (Neovison vison) in Poland. Eur J Wild Res 56:341-348

Bulte EH, Rondeau D (2005) Why compensating wildlife damages may be bad for conservation. J Wildl Manage 69:14-19

Callaghan DA, Kirby JS, Bell MC, Spray CJ (1998) Cormorant (Phalacrocorax carbo) occupancy and impact at stillwater game fisheries in England and Wales. Bird Study 45:1-17

Carss DN (1994) Killing of piscivorous birds at Scottish fin fish farms, 1984-87. Biol Conserv 68:181-188

Coluccy JM, Drobney RD, Graber DA, Sheriff SL, Witter DJ (2001) Attitudes of central Missouri residents toward local giant 
Canada geese and management alternatives. Wildl Soc Bull 29:116-123

Conover MR (2001) Resolving human-wildlife conflicts: the science of wildlife damage management. Lewis, CRC Press LLC, Boca Raton

Conover MR, Decker DJ (1991) Wildlife damage to crops: perceptions of agricultural and wildlife professionals in 1957 and 1987. Wildl Soc Bull 19:46-52

Daniel WN (ed) (1990) Applied nonparametric statistics. Thom Information, Belmont

Dobrowolski K (ed) (1995) Environmental-economic evaluation of fish ponds in Poland. IUCN, Warszawa

Dzięciołowski R, Goździewski J (1999) The reintroduction of the European Beaver Castor fiber in Poland: a success story. In: Busher PE, Dzięciołowski R (eds) Beaver protection. Management and utilisation in Europe and North America. Kluwer Academic/Plenum, New York, pp 31-35

Erb J, Boyce MS, Stenseth NC (2001) Spatial variation in mink and muskrat interactions in Canada. Oikos 93:365-375

FAO (2007) Regional review on aquaculture development 5. Central and Eastern European region-2005. FAO Fisheries Circular 1017/5, FAO, Rome

Freitas D, Gomes J, Sales-Luís T, Madruga L, Marques C, Baptista G, Rosalino LM, Antunes P, Santos R, Santos-Reis M (2007) Otters and fish farms in the Sado estuary: ecological and socioeconomic basis of a conflict. Hydrobiologia 587:51-62

Grimmet RFA, Jones TA (1989) Important Bird Areas in Europe. ICBP Technical Publ. no. 9, Cambridge

Halley D, Rosell F (2002) The beaver's reconquest of Eurasia: status, population development and management of a conservation success. Mamm Rev 32:153-178

Henle K, Alard D, Clitherow J, Cobb P, Firbank L, Kull T et al (2008) Identifying and managing the conflicts between agriculture and biodiversity conservation in Europe - a review. Agric Ecosyst Environ 124:60-71

IUCN (1997) Fishing for a living - the ecology and economics of fishponds in Central Europe. IUCN, Gland and Cambridge

Jędrzejewska B, Sidorovich VE, Pikulik MM, Jędrzejewski W (2001) Feeding habits of the otter and the American mink in Bialowieża Primeval Forest (Poland) compared to other Eurasian populations. Ecography 24:165-180

Kloskowski J (1999) Otter Lutra lutra predation in cypriniddominated habitats. Z Säugetierkd 64:201-209

Kloskowski J (2005a) Otter Lutra lutra damage at farmed fisheries in southeastern Poland, I: an interview survey. Wildl Biol 11:201206

Kloskowski J (2005b) Otter Lutra lutra damage at farmed fisheries in southeastern Poland, II: exploitation of common carp Cyprinus carpio. Wildl Biol 11:257-261

Kranz A (2000) Otters (Lutra lutra) increasing in Central Europe: from the threat of extinction to locally perceived overpopulation? Mammalia 64:357-368

Landis JR, Koch GG (1977) The measurements of observer agreement for categorical data. Biometrics 33:159-174
Lekuona JM (2002) Food intake, feeding behaviour and stock losses of cormorants, Phalacrocorax carbo, and grey herons, Ardea cinerea, at fish farm in Arcachon Bay (Southwest France) during breeding and non-breeding season. Folia Zool 51:23-24

McDonald RA, O'Hara K, Morrish DJ (2007) Decline of an invasive alien mink (Mustela vison) is concurrent with recovery of native otters. Divers Distrib 13:92-98

McKinstry MC, Anderson SH (1999) Attitudes of private and public land managers in Wyoming, USA, toward beaver. Environ Manage 23:95-101

Opačak A, Florijančić T, Horvat D, Ozimec S, Bodakoš D (2004) Diet spectrum of great cormorants (Phalacrocorax carbo sinensis L.) at the Donji Miholjac carp fishponds in eastern Croatia. Eur J Wildl Res 50:173-178

Rauschmayer F, Wittmer H, Berghöfer A (2008) Institutional challenges for resolving conflicts between fisheries and endangered species conservation. Mar Policy 32:178-188

Saberwal VK, Gibbs JP, Chellam R, Johnsingh AJT (1994) Lionhuman conflict in The Gir Forest, India. Conserv Biol 8:501-507

Sales-Luís T, Freitas D, Santos R, Santos-Reis M (2009) Key landscape factors for Eurasian otter Lutra lutra visiting rates and fish loss in estuarine fish farms. Eur J Wildl Res 55:345-355

Schwerdtner K, Gruber B (2007) A conceptual framework for damage compensation schemes. Biol Conserv 134:354-360

Sellitz C, Jahoda M, Deutsch M, Cook SW (1965) Research methods in social relations. Methuen and Co, London

Szücs I, Stundi L, Váradi L (2007) Carp farming in Central and Eastern Europe and a case study in multifunctional aquaculture. In: Leung PS, Lee C-S, O'Bryan PJ (eds) Species and system selection for sustainable aquaculture. Blackwell, Ames, pp 389-413

Tomiałojć L, Stawarczyk T (2003) The avifauna of Poland. Distribution, numbers and trends. PTPP "pro Natura", Wrocław (in Polish with English abstracts)

Treves A, Karanth KU (2003) Human-carnivore conflict and perspectives on carnivore managements worldwide. Conserv Biol 17:1491-1499

Treves A, Jurewicz R, Naughton-Treves L, Wilcove D (2009) The price of tolerance: wolf damage payments after recovery. Biodivers Conserv 18:4003-4021

Van Vessem J, Draulans D, de Bont AF (1985) The effects of killing and removal on the abundance of grey herons at fish farms. In Proceedings of the XVIIth Congress of the International Union of Game Biologists, Brussels, pp 337-343

West BC, Parkhurst JA (2002) Interactions between deer damage, deer density, and stakeholder attitudes in Virginia. Wildl Soc Bull 30:139-147

Young J, Richards C, Fischer A, Halada L, Kull T, Kuzniar A, Tartes U, Uzunov Y, Watt A (2007) Conflicts between biodiversity conservation and human activities in the central and eastern European countries. Ambio 36:545-550

Żurowski W, Kasperczyk B (1988) Effects of reintroduction of European beaver in the lowlands of the Vistula basin. Acta Theriol 33:325-338 